\title{
Severe ozone air pollution in the Persian Gulf region
}

\author{
J. Lelieveld ${ }^{1,2}$, P. Hoor ${ }^{2}$, P. Jöckel ${ }^{2}$, A. Pozzer ${ }^{1}$, P. Hadjinicolaou ${ }^{1}$, J.-P. Cammas ${ }^{3}$, and S. Beirle ${ }^{2}$ \\ ${ }^{1}$ Energy, Environment and Water Research Centre, The Cyprus Institute, 20 Kavafi Street, 1645 Nicosia, Cyprus \\ ${ }^{2}$ Max Planck Institute for Chemistry, Becherweg 27, 55128 Mainz, Germany \\ ${ }^{3}$ Observatoire Midi-Pyrénées, CNRS - Laboratoire d'Aérologie, 14 Avenue E. Belin, 31400 Toulouse, France
}

Received: 8 August 2008 - Published in Atmos. Chem. Phys. Discuss.: 29 September 2008

Revised: 23 January 2009 - Accepted: 16 February 2009 - Published: 20 February 2009

\begin{abstract}
Recently it was discovered that over the Middle East during summer ozone mixing ratios can reach a pronounced maximum in the middle troposphere. Here we extend the analysis to the surface and show that especially in the Persian Gulf region conditions are highly favorable for ozone air pollution. We apply the EMAC atmospheric chemistryclimate model to investigate long-distance transport and the regional formation of ozone. Further, we make use of available in situ and satellite measurements and compare these with model output. The results indicate that the region is a hot spot of photochemical smog where European Union air quality standards are violated throughout the year. Longdistance transports of air pollution from Europe and the Middle East, natural emissions and stratospheric ozone conspire to bring about relatively high background ozone mixing ratios. This provides a hotbed to strong and growing indigenous air pollution in the dry local climate, and these conditions are likely to get worse in the future.
\end{abstract}

\section{Introduction}

Ozone $\left(\mathrm{O}_{3}\right)$ plays a key role in atmospheric oxidation processes and photochemical air pollution. Although there is no general consensus about the critical levels for human health, environment agencies concur that 8-hourly levels in excess of 50-60 ppbv and a 1-hourly average of $\sim 80 \mathrm{ppbv}$ constitute health hazards (Ayres et al., 2006). Whereas high peak values are of particular importance for human health, permanent exposure to lower levels is also problematical (Bell et al., 2006). Furthermore, ambient mixing ratios of about 40

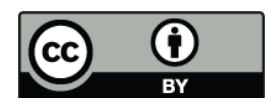

Correspondence to: J. Lelieveld (lelieveld@mpch-mainz.mpg.de) ppbv for extended periods of several months cause crop loss and damage to natural ecosystems (Emberson et al., 2003).

Ozone is a secondary pollutant, formed during the oxidation of reactive carbon compounds and catalyzed by nitrogen oxides $\left(\mathrm{NO}_{\mathrm{x}}=\mathrm{NO}+\mathrm{NO}_{2}\right)$, driven by ultraviolet sunlight. Conditions typically found in the subtropics are conducive for the formation of photochemical smog, and background ozone levels over the subtropical Atlantic have been observed to increase strongly by $\sim 5 \mathrm{ppbv} / \mathrm{decade}$ (Lelieveld et al., 2004). In the Mediterranean region the European Union phytotoxicity limit of $40 \mathrm{ppbv}$ and the health protection limit of 55 ppbv are often exceeded (Kouvarakis et al., 2002; Ribas and Peñuelas, 2004), which causes tens of thousands of premature mortalities per year (Gryparis et al., 2004; Duncan et al., 2008).

In a study of vertical ozone profiles in the Middle East $\mathrm{Li}$ et al. (2001) used a chemistry-transport model and predicted a regional summertime $\mathrm{O}_{3}$ maximum in the middle troposphere in excess of $80 \mathrm{ppbv}$. Satellite measurements of tropospheric $\mathrm{NO}_{2}$ confirm that $\mathrm{O}_{3}$ precursor concentrations can be high in this area (van der A, 2008; Stavrakou et al., 2008). Li et al. (2001) concluded that transport from the stratosphere does not contribute significantly to the $\mathrm{O}_{3}$ maximum. Yet, a study of stratosphere-troposphere exchange (STE) over the eastern Mediterranean indicates that crosstropopopause transport can be intense, related to the distinct summertime meteorological conditions over South Asia and the Arabian Peninsula (Traub and Lelieveld, 2003).

Here we advance these investigations by applying the EMAC atmospheric chemistry-general circulation model that represents STE processes as well as the large-scale transport and photochemistry of air pollution (Roeckner et al., 2006; Jöckel et al., 2006). Our focus is on the Persian Gulf region, located downwind of major pollution areas and with

Published by Copernicus Publications on behalf of the European Geosciences Union. 


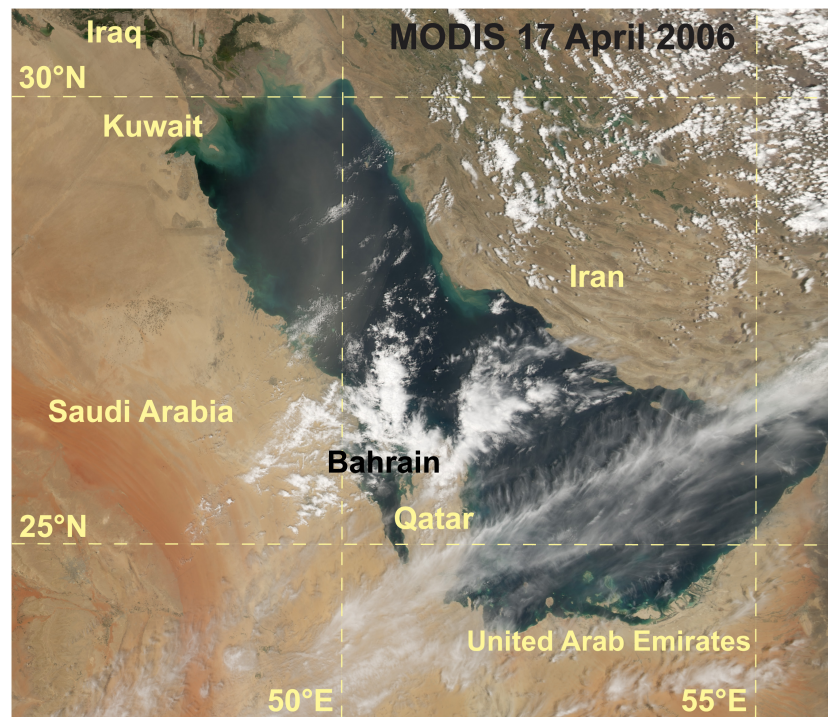

Fig. 1. Satellite image of the Persian Gulf region by the Moderate resolution Imaging Spectroradiometer taken on 17 April 2006, showing thin clouds and desert dust transported from the west (NASA Visible Earth).

substantial and growing local sources. It should be noted that this region is also subject to aerosol pollution, including desert dust (Fig. 1), though here we concentrate on ozone and the meteorological conditions that promote photochemical air pollution.

\section{EMAC model description}

The numerical model simulations have been performed with the 5th generation European Centre - Hamburg general circulation model (GCM), ECHAM5 (Roeckner et al., 2006) coupled to the Modular Earth Submodel System, MESSy (Jöckel et al., 2006), applied to Atmospheric Chemistry (EMAC). The model includes a comprehensive representation of tropospheric and stratospheric dynamical, cloud, radiation, multiphase chemistry and emission-deposition processes. We applied the model at T42 resolution, being about $2.8^{\circ}$ in latitude and longitude. In addition we performed a simulation at $\mathrm{T} 106\left(\sim 1.1^{\circ}\right)$ for the months June-August 2006 to test the sensitivity of the results to the model resolution. The vertical grid structure resolves the lower and middle atmosphere with 90 layers from the surface to a top layer centered at $0.01 \mathrm{hPa}$ (Giorgetta et al., 2006). The average midpoint of the lowest layer is at $30 \mathrm{~m}$ altitude (terrain following sigma coordinates) and the lower $1.5 \mathrm{~km}$ of the model (up to $857 \mathrm{hPa}$ ) is represented by five layers.

This model configuration was selected because it explicitly represents stratosphere-troposphere interactions and includes a comprehensive representation of atmospheric chemistry, and also because it has been extensively tested and doc- umented. The conclusion from the comprehensive model evaluation by Jöckel et al. (2006) was that in spite of minor shortcomings, mostly related to the relatively coarse T42 resolution and the neglect of inter-annual changes in biomass burning emissions, the main characteristics of the trace gas distributions are generally reproduced well.

The chemistry calculations are performed using a kinetic preprocessor to describe a set of 177 gas phase, 57 photo-dissociation and 81 heterogeneous tropospheric and stratospheric reactions (Sander et al., 2005). Details of the chemical mechanism (including reaction rate coefficients and references) can be found in the electronic supplement (http://www.atmos-chem-phys.net/5/445/ 2005/acp-5-445-2005.html). The model also carries a tracer for stratospheric ozone $\left(\mathrm{O}_{3} \mathrm{~s}\right)$, which enables a comparison with $\mathrm{O}_{3}$ that is photochemically formed within the troposphere (Jöckel et al., 2006). The $\mathrm{O}_{3} \mathrm{~s}$ tracer is set to $\mathrm{O}_{3}$ throughout the stratosphere and follows the transport and destruction processes of ozone in the troposphere, however, is not recycled through $\mathrm{NO}_{\mathrm{x}}$ chemistry (including titration by $\mathrm{NO}$ and recycling into $\mathrm{O}_{3}$ ). If $\mathrm{O}_{3}$ s re-enters the stratosphere it is re-initialized at stratospheric values (Roelofs and Lelieveld, 1997).

A more detailed description and a discussion of how well our GCM represents stratosphere-troposphere exchange (STE) processes and their dependence on resolution can be found in Kentarchos et al. (2000). STE is forced by the largescale dynamics (wave forcing) which is well resolved by the model at T42. Further improvements are reported by Giorgetta et al. (2006) who increased the vertical resolution of the model, as used in the present study. Sensitivity simulations by Kentarchos et al. (2000) indicate that at higher horizontal resolution (i.e. T63) the STE flux may be about 10\% larger than at T42, whereas further resolution increases (i.e. T106) do not lead to additional STE flux changes. Kentarchos et al. also reported excellent agreement between simulated tropopause folding events and analyses of the European Centre for Medium-range Weather Forecasts (ECMWF).

For the representation of natural and anthropogenic emissions and dry deposition of trace species, including micrometeorological and atmosphere-biosphere interactions, wet deposition by different types of precipitation, and multiphase chemistry processes we refer to the detailed descriptions by Ganzeveld et al. (2006), Kerkweg et al. (2006), Tost et al. (2006) and additional articles in a special issue of Atmos. Chem. Phys. (http://www.atmos-chem-phys.net/ special_issue22.html). The results of the tropospheric and stratospheric chemistry calculations, using a number of diagnostic model routines, have been compared to in situ and remote sensing measurements (Jöckel et al., 2006; Lelieveld et al., 2007; Pozzer et al., 2007).

The model has been nudged towards actual meteorological conditions for the year 2006 based on operational analyses of the ECMWF. A Newtonian relaxation term has been added to the prognostic variables for vorticity, divergence, 


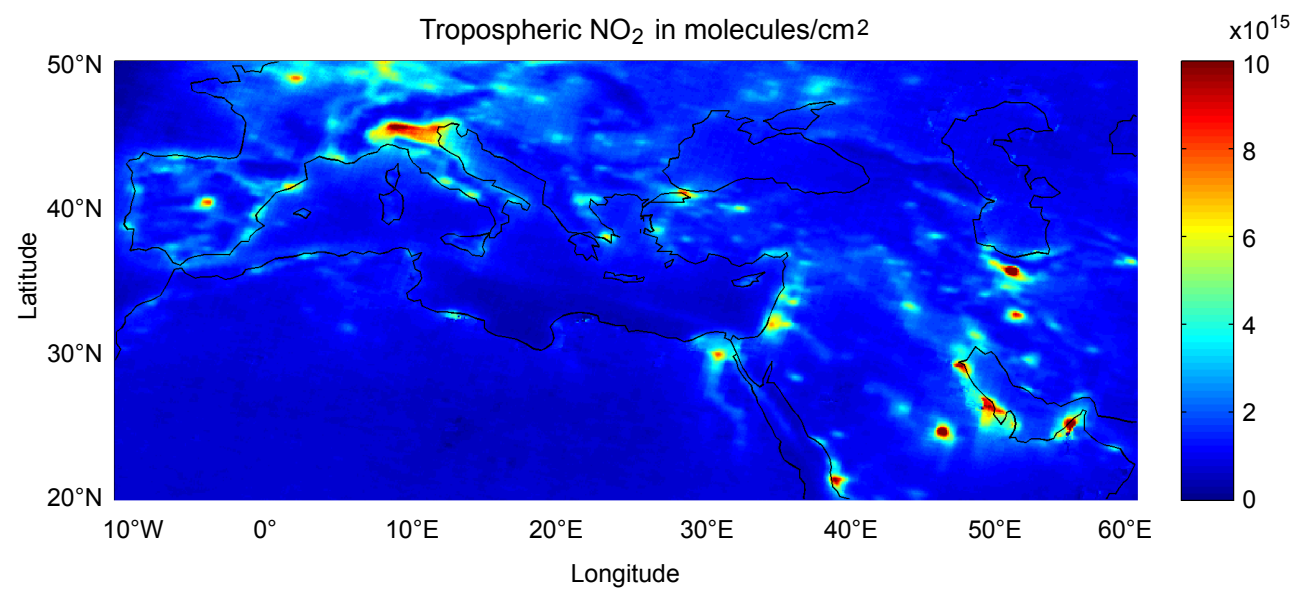

Fig. 2. SCIAMACHY satellite image of tropospheric $\mathrm{NO}_{2}$ columns, averaged over 2003-2007, showing several hot spots over major cities in the Middle East and in particular around the Persian Gulf.

temperature and surface pressure (Lelieveld et al., 2007). We avoid inconsistencies between our GCM and the ECMWF boundary layer representations by leaving the lowest three model levels free (apart from surface pressure), while the nudging increases stepwise in four levels up to about $700 \mathrm{hPa}$ and tapers off to zero at $200 \mathrm{hPa}$. The nudging coefficients are chosen to be small to allow maximum internal consistency in the model calculations of meteorological processes.

\section{Anthropogenic $\mathrm{NO}_{\mathrm{x}}$ emissions}

The database of anthropogenic emissions used as boundary conditions in the EMAC model is EDGAR 3.2 (fast track) (van Aardenne et al., 2005; Ganzeveld et al., 2006). It seems likely that emissions of ozone precursors, most importantly of $\mathrm{NO}_{\mathrm{x}}$, are fairly well constrained for Europe and the North America, but possibly less well for many other regions including the Middle East. In Table 1 we present the EDGAR 3.2 emissions of $\mathrm{NO}_{\mathrm{x}}$ in the Middle East, referring to the year 2000.

The main $\mathrm{NO}_{\mathrm{x}}$ source category is transport (59\%), being dominated by road traffic, except in the United Arab Emirates (UAE) where emissions from international shipping are largest. The second and third most important $\mathrm{NO}_{\mathrm{x}}$ emission categories are power generation and industry, respectively. Biomass burning is only a minor source. The countries with the strongest $\mathrm{NO}_{\mathrm{x}}$ sources in the region are Iran, Turkey, the UAE and Saudi Arabia. To put these data into perspective, we may compare the Middle East with North America (population of both regions $\sim 350$ million) which releases about $22000 \mathrm{Gg} / \mathrm{yr}\left(\right.$ as $\mathrm{NO}_{2}$ ) (compared to $6700 \mathrm{Gg} / \mathrm{yr}$ in the Middle East). The EDGAR 3.2 $\mathrm{NO}_{\mathrm{x}}$ emissions for California, which has a similar size and population as the Gulf region, amount to $1320 \mathrm{Gg} / \mathrm{yr}$. In California power generation contributes $14 \%$, transport $66 \%$ and industry $16 \%$, indicat- ing that the fractional contributions by source sector are not strongly different than in the Middle East, although transport is even more dominant.

Although we have no means to quantitatively test the EDGAR 3.2 emission database for the region of interest, Fig. 2 presents Scanning Imaging Absorption Spectrometer for Atmospheric Chartography (SCIAMACHY) satellite data of tropospheric $\mathrm{NO}_{2}$ vertical column densities for the Mediterranean and the Middle East in the period 2003-2007, obtained at a resolution of approximately $30 \times 60 \mathrm{~km}^{2}$. These $\mathrm{NO}_{2}$ column densities have been retrieved with the spectral analysis method of Leue et al. (2001), and the further processing and testing against ground-based remote sensing measurements in polluted air have been described by Chen et al. (2008).

Because of the short lifetime of $\mathrm{NO}_{2}$ (about one day) it is detected by SCIAMACHY close to the $\mathrm{NO}_{\mathrm{x}}$ sources, and these measurements provide an indication of the emission strengths. Remarkably, several locations in the Middle East are characterized by much higher $\mathrm{NO}_{2}$ column densities than major cities in Europe such as Paris, Madrid, Athens and Istanbul. The $\mathrm{NO}_{2}$ columns may be compared with those in the Milan Basin (Fig. 2), a region notorious for poor air quality (Neftel et al., 2002). Especially Riyadh, Jeddah, Bahrain, the region Dhahran-Dammam-Al Jubayl, Dubai, Kuwait, Tehran, Esfahan, and to a lesser extent Cairo and Tel Aviv can be clearly identified as strong $\mathrm{NO}_{\mathrm{x}}$ sources.

This is especially noteworthy considering that the lifetime of $\mathrm{NO}_{2}$ in the Middle East is shorter than in Europe because the geographical location is highly favorable for the formation of hydroxyl $(\mathrm{OH})$ radicals that rapidly transform $\mathrm{NO}_{2}$ into nitric acid. The $\mathrm{OH}$ is formed by the photodissociation of ozone in the presence of water vapor, and is catalytically recycled by $\mathrm{NO}_{\mathrm{x}}$. In Fig. 3 we present the observed upward tendencies of $\mathrm{NO}_{2}$ and lower tropospheric $\mathrm{O}_{3}$ in several locations around the Gulf derived from SCIAMACHY data and 
Table 1. $\mathrm{NO}_{\mathrm{x}}$ emissions in the Middle East (in $\mathrm{Gg} \mathrm{NO}_{2}$ /year) from EDGAR 3.2.

\begin{tabular}{|c|c|c|c|c|c|c|}
\hline & $\begin{array}{l}\text { Power } \\
\text { generation }\end{array}$ & $\begin{array}{l}\text { Residential } \\
\text { biofuel use }\end{array}$ & Transport $^{\mathrm{a}}$ & Industry ${ }^{b}$ & $\begin{array}{l}\text { Biomass } \\
\text { burning }\end{array}$ & Total \\
\hline Egypt & 158 & 75 & 444 & 143 & - & 820 \\
\hline UAE & 82 & 1 & 853 & 35 & - & 971 \\
\hline Bahrain & 25 & 1 & 24 & 19 & - & 69 \\
\hline Cyprus & 10 & - & 27 & 6 & 1 & 44 \\
\hline Iran & 325 & 33 & 711 & 204 & 18 & 1291 \\
\hline Iraq & 53 & 15 & 299 & 42 & - & 409 \\
\hline Israel & 141 & - & 163 & 30 & 4 & 338 \\
\hline Jordania & 20 & 3 & 38 & 12 & - & 73 \\
\hline Kuwait & 62 & - & 54 & 22 & - & 138 \\
\hline Lebanon & 15 & 2 & 29 & 13 & - & 59 \\
\hline Oman & 24 & 1 & 28 & 6 & - & 59 \\
\hline Qatar & 75 & - & 22 & 14 & - & 111 \\
\hline $\mathrm{S}-$ Arabia & 169 & 4 & 625 & 149 & 8 & 955 \\
\hline Syria & 68 & 8 & 147 & 36 & 6 & 265 \\
\hline Turkey & 251 & - & 409 & 260 & 66 & 986 \\
\hline Yemen & 5 & 9 & 53 & 42 & - & 109 \\
\hline Total & 1483 & 152 & 3926 & 1033 & 103 & 6697 \\
\hline$\%$ of total & $22 \%$ & $2 \%$ & $59 \%$ & $15 \%$ & $2 \%$ & $100 \%$ \\
\hline
\end{tabular}

${ }^{a}$ All transport sectors on land, air and sea. ${ }^{b}$ Including oil/iron/steel production, non-ferro, pulp and paper, construction, waste incineration.

${ }^{\mathrm{c}}$ Forest and savanna fires, agricultural waste burning.

MOZAIC aircraft measurements (see Sect. 4). It thus appears that $\mathrm{NO}_{\mathrm{x}}$ emissions in the Middle East are growing rapidly so that it is conceivable that the EDGAR 3.2 emission database, referring to the year 2000, and therefore our model underestimate regional $\mathrm{NO}_{\mathrm{x}}$ levels for the year 2006.

\section{Model results compared to observations}

Whilst the model has been extensively tested in many applications, an ozone measurement database for the Middle East is to a large degree lacking. For the free troposphere we use ozone measurements of the MOZAIC program (Measurements of Ozone and Water Vapor by In-service Airbus Aircraft) (Thouret et al., 1998; Zbinden et al., 2006) (see also http://www.aero.obs-mip.fr/mozaic/). It appears that for 2000 and 2004 relatively extensive datasets are available from aircraft ascents and descents over Bahrain $\left(26^{\circ} \mathrm{N}\right.$, $\left.50.5^{\circ} \mathrm{E}\right)$, Dubai $\left(25^{\circ} \mathrm{N}, 55^{\circ} \mathrm{E}\right)$, Kuwait $\left(29^{\circ} \mathrm{N}, 48^{\circ} \mathrm{E}\right)$ and Riyadh $\left(24.5^{\circ} \mathrm{N}, 46.5^{\circ} \mathrm{E}\right)$, and we compare the measurements with previous model output for these years (Jöckel et al., 2006). Figure 4 shows that the pronounced middle tropospheric ozone maximum in summer ( $\geq 80 \mathrm{ppbv})$, which was predicted by Li et al. (2001), is reproduced.

In addition we use the satellite measurements of tropospheric ozone by the Tropospheric Emission Spectrometer (TES) on the AURA satellite (Worden et al., 2007; Osterman et al., 2008). The comparison of daily TES observations (version 2) to ozone soundings indicated a mean positive bias of 3-9 ppbv in the lower troposphere (Nassar et al., 2008). In our study we compare daily level 3 data (version 3 ) to EMAC model output. The EMAC data are interpolated in space and time to the geolocations of the satellite after evaluating the ozone quality flag of the TES data. EMAC profiles are regridded to the vertical resolution of the TES retrieval levels, and the averaging kernel for each individual TES profile is applied to the corresponding EMAC profile. The available (remaining) number of profiles after applying the TES quality flags is about 1500 per day, which are compared to the EMAC data on the same horizontal and vertical grid.

Figure 5 compares the TES data to our model results, representative for three levels in the troposphere between 908.5 and $261 \mathrm{hPa}$ over the Persian Gulf region. The individual TES data points produce a similar variability as the EMAC model results. Considering the difference in resolution and because the model nudging to ECMWF analyses approximates and not mimics meteorological conditions, ideal agreement cannot be expected. From the agreement between the mean mixing ratios and the probability density functions we conclude that the model adequately represents atmospheric chemistry conditions in the Gulf region. 

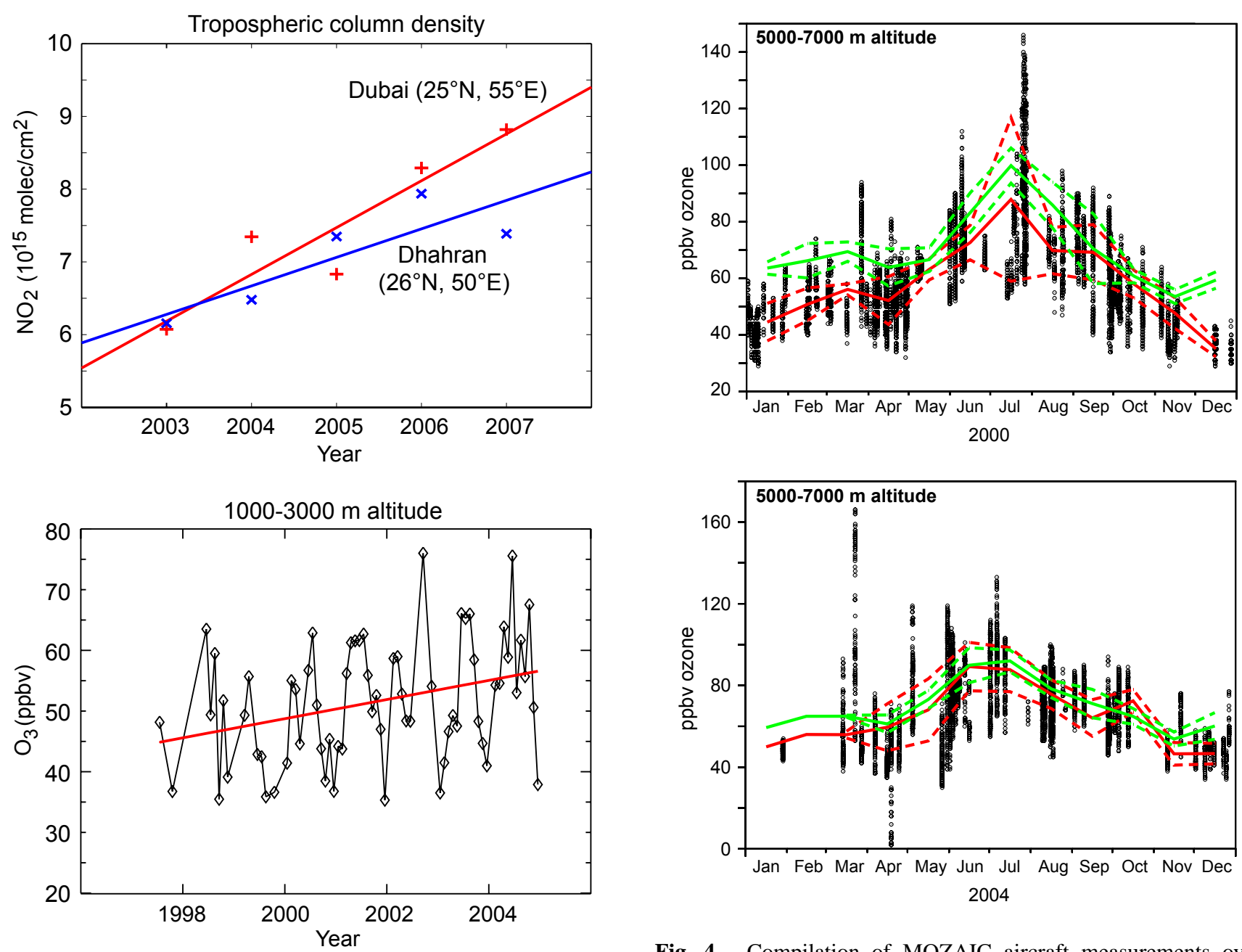

Fig. 3. Top: Annual mean column densities of $\mathrm{NO}_{2}$ over Dubai and Dhahran (within a radius of $0.5^{\circ}$ around the cities) derived from SCIAMACHY satellite data. The linear upward trends are 6.4 and $3.9 \times 10^{14}$ molecules $/ \mathrm{cm}^{2} /$ year, respectively. Bottom: individual data points of ozone over Kuwait, Dubai, Dhahran and Riyadh obtained by MOZAIC aircraft measurements between 1 and $3 \mathrm{~km}$ altitude. The linear upward trend is $1.57 \pm 0.57(1 \sigma)$ ppbv/year (level of statistical significance is $99 \%$ ).

\section{Meteorology}

The large-scale Hadley circulation, driven by deep tropical cumulonimbus cloud formation and intense precipitation, is accompanied by descent in the subtropics. In the winter hemisphere the Hadley cell is most pronounced, which is associated with the relatively strong meridional heating gradient. The low level flow in the subtropics is characterized by vast anticyclones, which occupy about $40 \%$ of the Earth's surface (Rodwell and Hoskins, 2001).

The Middle East, being under the downward branch of the Hadley circulation, is among the warmest and driest in the world. From a space perspective, the atmospheric radiation 

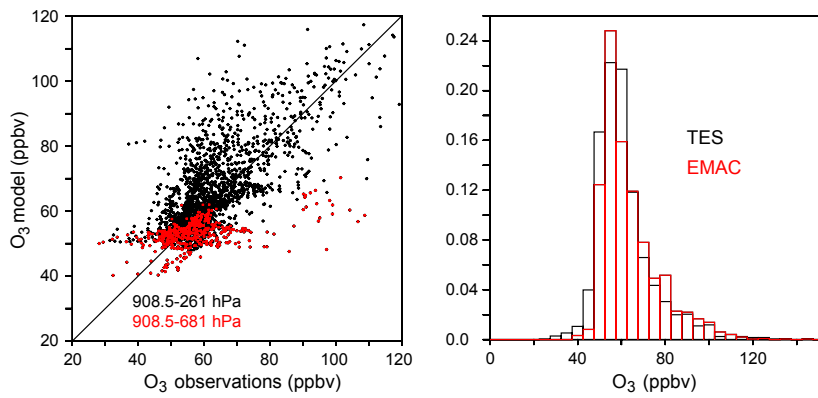

Fig. 5. Compilation of TES satellite observations compared to EMAC model calculated $\mathrm{O}_{3}$ in the troposphere in the region of 25 $30^{\circ} \mathrm{N}$ latitude and $45-55^{\circ} \mathrm{E}$ longitude in the year 2006. Left: correlation plot in which the solid line indicates ideal agreement. The red symbols highlight the $\mathrm{O}_{3}$ mixing ratios at the lowest altitude level resolved by TES. Right: probability density functions.

that the tropics are expanding (Seidel et al., 2008) and the Asian monsoon will intensify under the influence of global warming (IPCC, 2007), it may be expected that subsidence and dryness over the eastern Mediterranean and the Middle East will increase, being a robust finding of climate modeling (Giorgi and Bi, 2005; Held and Soden, 2006; Diffenbaugh et al., 2007; Sun et al., 2007).

In summer the hot desert conditions give rise to a heat low with cyclonic flow over the southern Arabian Peninsula. In the south the circulation is reinforced by the summer monsoon that carries air from East Africa. Over the Persian Gulf it converges with the northwesterly flow from the Mediterranean. The latter carries European air pollutants southward to North Africa and the Middle East (Kallos et al., 1998; Lelieveld et al., 2002; Stohl et al., 2002; Duncan et al., 2004). In winter the Atlantic westerlies carry relatively clean air masses over the Mediterranean towards the Gulf. From the autumn to spring winds over the Gulf are more variable than in summer, nevertheless often carrying air masses southward, e.g. from Iran. Occasionally, storms carry desert dust plumes over the region, though during the winter wet season the dust and air pollution are reduced.

In summer the Asian monsoon surface trough and the Arabian heat low are associated with anticyclones in the upper troposphere. The tropical easterly jet stream at the southern flank of the monsoon anticyclone is diverted toward the eastern Mediterranean by the Arabian anticyclone (Barret et al., 2008). Convergence of this flow with the polar front jet stream accelerates the horizontal wind and increases the horizontal and vertical wind shear, creating a jet streak and tropopause folds (Traub and Lelieveld, 2003). An investigation of ECMWF analyses by Sprenger et al. (2003) shows that tropopause folds preferentially occur in the subtropics during summer, forming almost permanent features. This demonstrates the occurrence of distinct maxima of crosstropopause transport in the region, e.g. over Turkey and

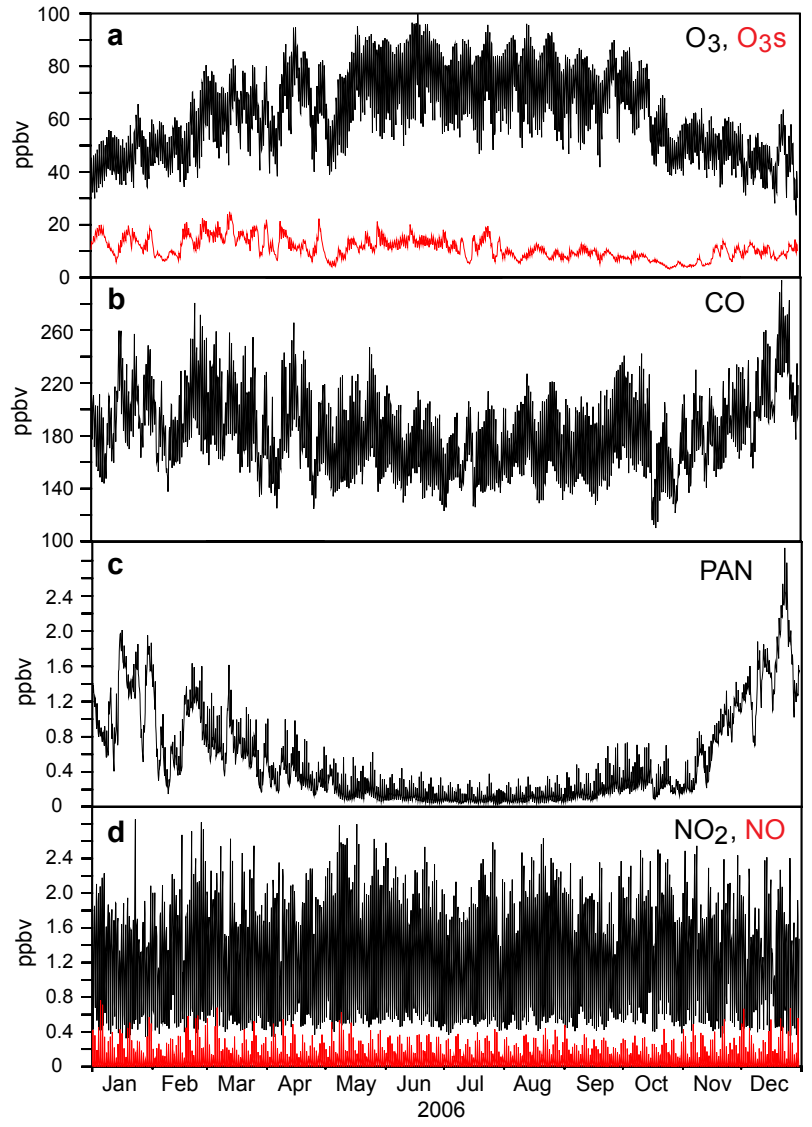

Fig. 6. Model calculated $\mathrm{O}_{3}, \mathrm{CO}, \mathrm{PAN}$ and $\mathrm{NO}_{\mathrm{x}}$ near the surface in the region of $25-30^{\circ} \mathrm{N}$ and $45-55^{\circ} \mathrm{E}$. In the top panel the red line indicates the contribution by $\mathrm{O}_{3}$ transported from the stratosphere $\left(\mathrm{O}_{3} \mathrm{~s}\right)$.

Afghanistan, associated with the northern edge of the monsoon anticyclone. The tropopause folding events carry ozone from the stratosphere and these air masses descend over the eastern Mediterranean and the Middle East.

\section{Regional ozone hot spot}

Figure 6a shows the daily and annual profiles of ozone near the surface over the Persian Gulf, averaged over a region of $5^{\circ}$ latitude and $10^{\circ}$ longitude, i.e. an area of about 0.5 million $\mathrm{km}^{2}$ (comparable to the size of California). Figure 6a also shows the contribution by ozone transported from the stratosphere $\left(\mathrm{O}_{3} \mathrm{~s}\right)$. It thus appears that most of the ozone is formed photochemically within the troposphere, although the contribution by $\mathrm{O}_{3} \mathrm{~s}$ is non-negligible. In winter the mean diel $\mathrm{O}_{3}$ variation is about $10-15 \mathrm{ppbv}$, related to photochemical ozone formation during daytime and titration by NO emissions and dry deposition in the nocturnal boundary layer. In summer the diel variation is larger, 20-30 ppbv, owing to the rapid formation during daytime. 


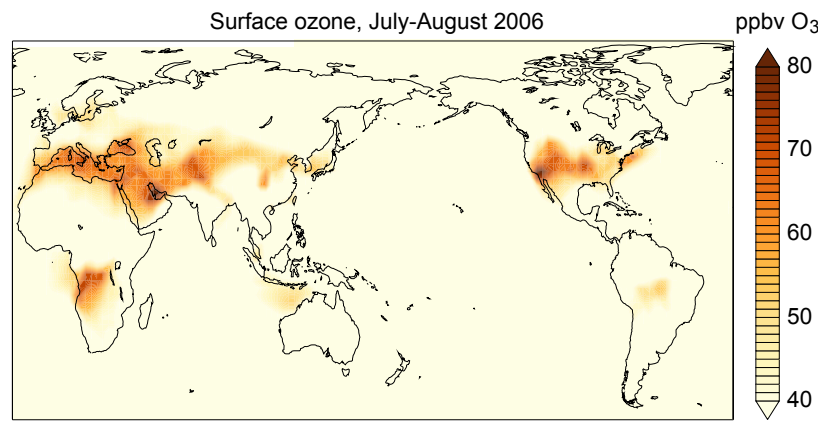

Fig. 7. Model calculated mean surface $\mathrm{O}_{3}$ in excess of $40 \mathrm{ppbv}$ averaged over the period July-August 2006, highlighting the subtropical band of ozone smog and pronounced hot spots over the Los Angeles and Persian Gulf regions.

The annual ozone minimum occurs in late December when the intensity of sunlight is lowest, whereas the relative contribution by STE is largest $(\sim 30 \%)$. The regional ozone levels are highest in summer, on average about 75 ppbv, while daytime values often exceed 80 ppbv. Note that these high mixing ratios occur throughout the Gulf region, providing a hotbed for local smog formation in urban and industrial areas. Importantly, the diel mean $\mathrm{O}_{3}$ mixing ratios substantially exceed $40 \mathrm{ppbv}$ throughout the year, hence the EU air quality standard for phytotoxicity is permanently violated. Furthermore, the EU health protection limit is strongly exceeded between February and October.

The average global distribution of $\mathrm{O}_{3}$ mixing ratios during summer is shown in Fig. 7 and the regional monthly means in Fig. 8, further illustrating that the Gulf region is a hot spot of notoriously high ozone. Note that we use a color scale from $40-80 \mathrm{ppbv}$ and upward to emphasize where air quality standards are violated. The mean wind vectors near the surface indicate that the Gulf is downwind of air pollution sources in the Mediterranean region and the Middle East.

Figure $6 \mathrm{~b}$ presents the regional mixing ratios of carbon monoxide (CO), being an indicator of air pollution. The $\mathrm{CO}$ levels are generally high, comparable to industrialized environments in Europe. A previous analysis of air pollution transports over the eastern Mediterranean showed that during summer extensive fire activity north of the Black Sea plays an important role (Lelieveld et al., 2002). The biomass burning plumes are carried southward to the Mediterranean and subsequently to the Middle East. The synoptic variability of $\mathrm{O}_{3}$ follows that of $\mathrm{CO}$, i.e. on time scales of days to weeks, which underscores that the ozone is to a large degree produced in polluted air. The regional mean $\mathrm{NO}_{\mathrm{x}}$ levels are between 1-1.5 ppbv, close to the optimum of the ozone formation efficiency per $\mathrm{NO}_{\mathrm{x}}$ molecule emitted.

Figure $6 \mathrm{c}$ shows peroxyacetylnitrate (PAN), a noxious pollutant formed from hydrocarbons and $\mathrm{NO}_{\mathrm{x}}$. The synoptic variability of PAN correlates with both $\mathrm{CO}$ and $\mathrm{O}_{3}$, whereas its seasonality anticorrelates with $\mathrm{O}_{3}$. PAN is decomposed

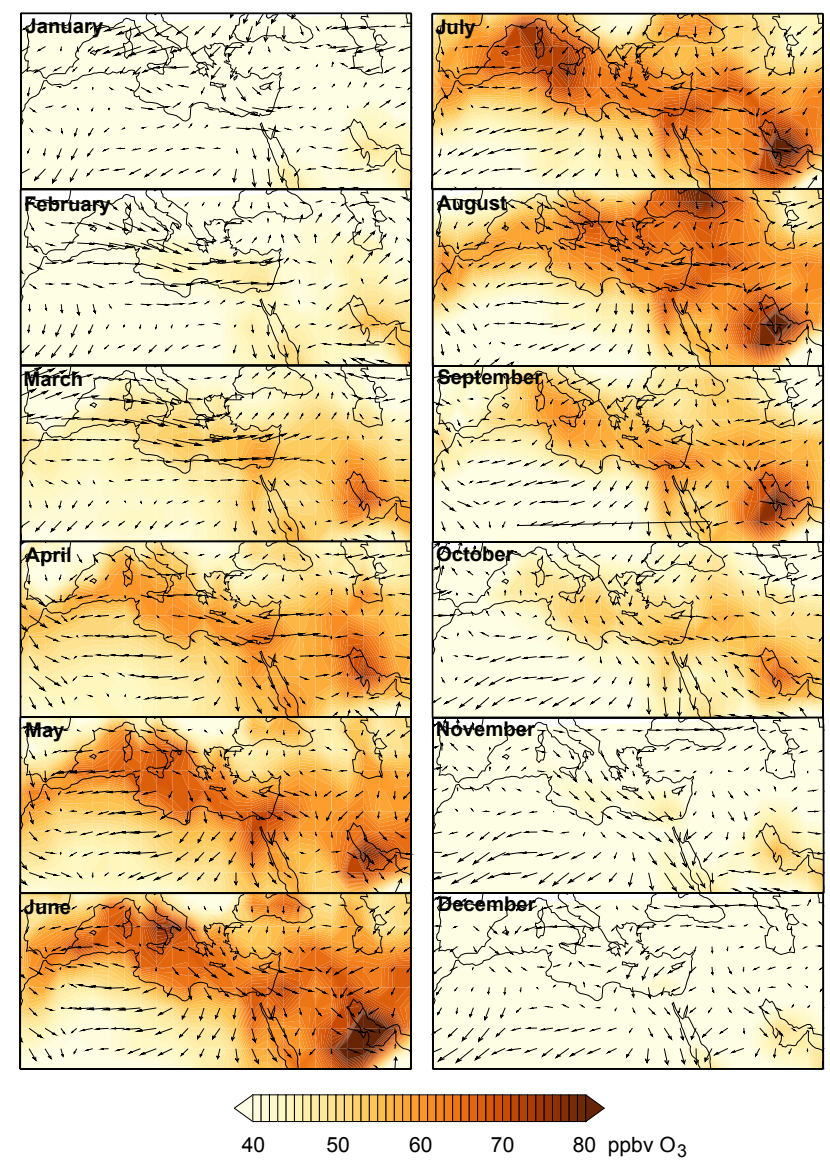

Fig. 8. Model calculated monthly mean surface $\mathrm{O}_{3}$ in excess of $40 \mathrm{ppbv}$ in the period January to December 2006. The arrows indicate the mean surface winds.

thermally so that in summer its lifetime is short. On the other hand, PAN builds up in winter, illustrated by the steep increase in November and December. Because of its increasing lifetime with decreasing temperature, PAN can act as a reservoir species of $\mathrm{NO}_{\mathrm{x}}$ (Singh et al., 1998). It is formed during transport from polluted regions upwind and can thermally decompose over the relatively warm Gulf region where it can add to ambient $\mathrm{NO}_{\mathrm{x}}$ levels.

Figure $6 \mathrm{~d}$ shows that the mean $\mathrm{NO}_{\mathrm{x}}$ mixing ratio near the surface in the Gulf region is rather constant throughout the year, even though the boundary layer is deeper in summer owing to the more dynamic convective mixing associated with surface heating. The consequent summertime dilution of local $\mathrm{NO}_{\mathrm{x}}$ emissions in the convective boundary layer appears to be compensated by a reduced trapping of $\mathrm{NO}_{\mathrm{x}}$ in the reservoir gas PAN connected to its more efficient thermal decomposition (Fig. 6c).

The transport and regional chemistry characteristics of ozone and precursor gases give rise to year round high ozone mixing ratios. Our model results suggest that in the entire region from Riyadh to Dubai, during all seasons, a 


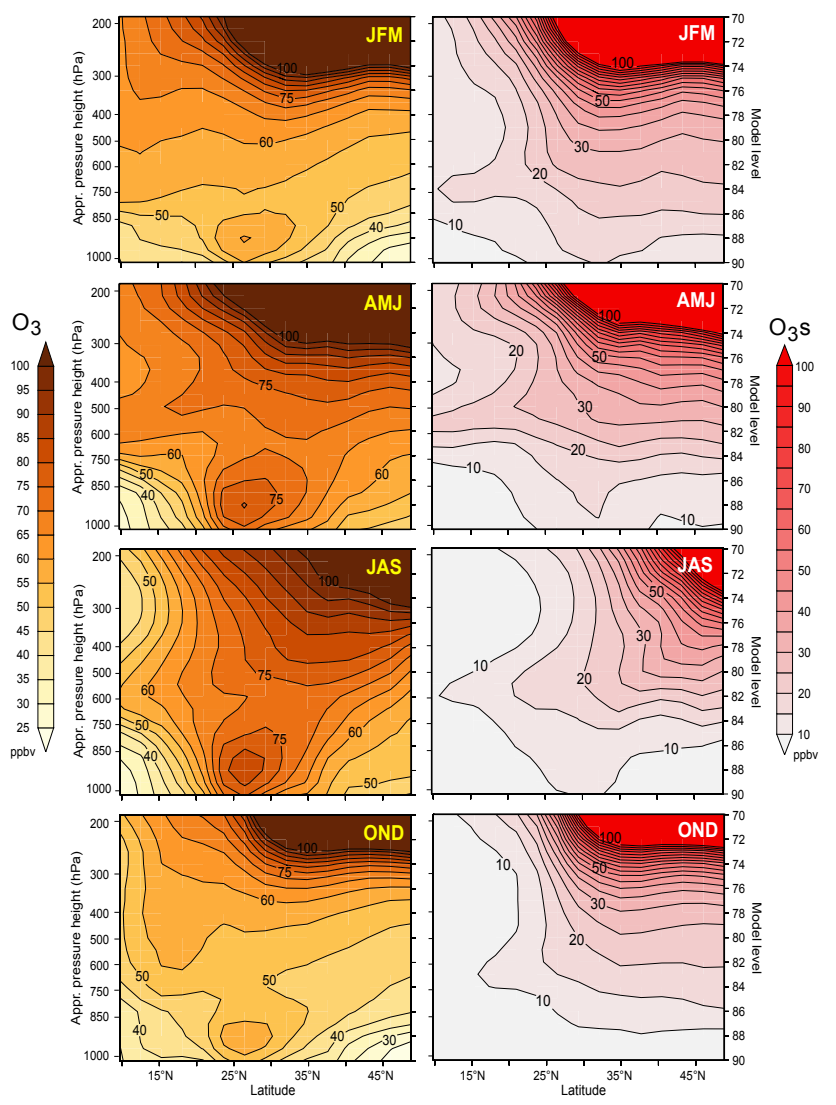

Fig. 9. Model calculated 3-monthly mean zonal and vertical distributions of $\mathrm{O}_{3}$ (left) and $\mathrm{O}_{3}$ originating in the stratosphere $\left(\mathrm{O}_{3} \mathrm{~s}\right.$, right) averaged over the $45-55^{\circ} \mathrm{E}$ longitude belt.

distinct ozone maximum is located between the surface and $\sim 750 \mathrm{hPa}$ (Fig. 9). Clearly the Gulf is a convergence region of long-distance transported air pollution, which fosters strong local ozone formation by indigenous emissions of $\mathrm{NO}_{\mathrm{x}}$ and reactive hydrocarbons in industrial and urban areas. The regional ozone maximum is most pronounced in summer when the meteorological conditions are auspicious for photo-smog.

\section{Stratosphere-troposphere exchange}

Although the contribution by STE to surface ozone may seem limited it is interesting to examine its role throughout the tropospheric column. Previously, Li et al. (2001) investigated the middle tropospheric ozone maximum over the Middle East in summer. At variance with $\mathrm{Li}$ et al. our model results point to a significant role of STE (Fig. 9). Our results suggest that in the Gulf region $\mathrm{O}_{3}$ s contributes about two thirds to the tropospheric ozone column in winter whereas this is still about one quarter in summer. Nevertheless, we agree with $\mathrm{Li}$ et al. that also in the middle and upper troposphere in situ photochemical $\mathrm{O}_{3}$ formation plays an important role,

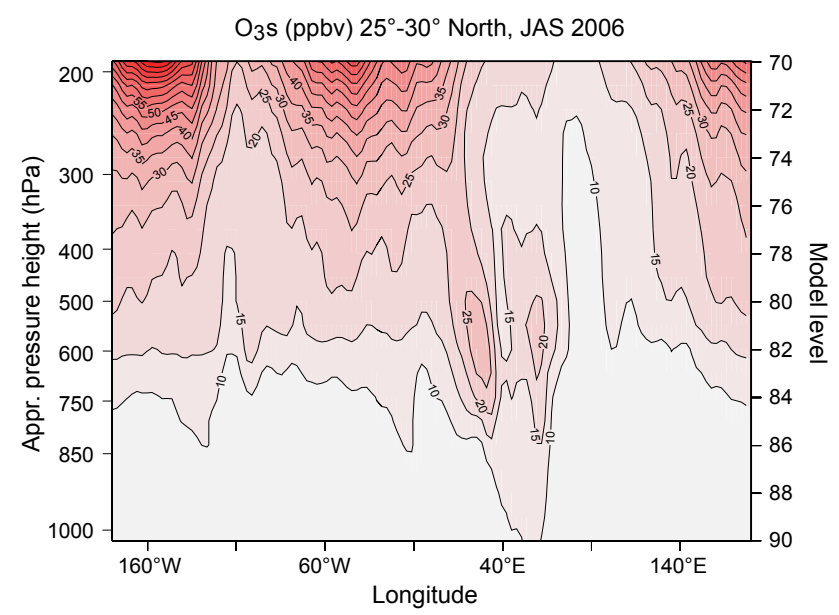

Fig. 10. Model calculated tropospheric $\mathrm{O}_{3}$ originating in the stratosphere $\left(\mathrm{O}_{3} \mathrm{~s}\right)$ averaged between $25-30^{\circ} \mathrm{N}$ latitude in the period July to September 2006.

and the anthropogenic component substantially contributes to the radiative forcing of climate.

In fact, STE derived ozone penetrates remarkably far south over the Middle East. Especially in winter and spring an $\mathrm{O}_{3} \mathrm{~s}$ maximum reaches deeply into the tropics in the lower free troposphere. Interestingly, a second $\mathrm{O}_{3}$ s maximum touches the surface near the Gulf around $30^{\circ} \mathrm{N}$ latitude, both in summer and winter. This corresponds to the results in Fig. 6a, showing that the contribution of $\mathrm{O}_{3} \mathrm{~s}$ is significant during the entire year.

Figure 10 presents a global and longitudinal cross section of $\mathrm{O}_{3}$ s during summer, averaged between $25-30^{\circ} \mathrm{N}$ latitude. The influence of deep convection in the South Asian monsoon region, around $90^{\circ} \mathrm{E}$ (near Mt. Everest), is apparent from the relatively low $\mathrm{O}_{3}$ s mixing ratios throughout the troposphere. To the west, between about 500 and $600 \mathrm{hPa}$, two $\mathrm{O}_{3}$ s maxima appear, resulting from deep tropopause folding events. In particular the one near $30^{\circ} \mathrm{E}$ represents unusually deep subtropical STE. Figure 10 illustrates that a tongue of $\mathrm{O}_{3}$ s reaches the surface over the Persian Gulf, unique in the subtropics.

\section{Comparison with other locations}

A combination of factors thus contributes to the ozone maximum over the Gulf. To put this into perspective we compare with other subtropical locations in both hemispheres.

Since our global model is not ideal for investigating local urban and industrial conditions, we selected locations that are representative of larger areas. The largest city in the world in terms of surface area is Los Angeles, also notorious for high ozone levels. Although the Los Angeles emissions of CO per capita are among the highest in the world, its emission normalized per surface area is the lowest of the 20 largest 
cities (Gurjar et al., 2008). This is indicative of a relatively widespread and uniform source distribution.

For our comparison we define a "greater Los Angeles area" with a size close to a single grid cell in our model, also encompassing some ocean area and surrounding cities such as Pasadena, Riverside and San Bernardino. Similarly, we define a "greater Bahrain area", which includes a fraction of the Gulf, part of Qatar and several coastal cities in Saudi Arabia.

Figure 11 presents a comparison between these two polluted areas and also to more rural locations in southern China (Hunan), western Australia, and an area over the subtropical Pacific near Midway, downwind of East Asia. None of these regions is free of anthropogenic influence while the level of $\mathrm{O}_{3}$ decreases in the mentioned order (from the top down in Fig. 11). Figure 11 shows that all of these subtropical locations, irrespective of their remoteness, have ozone mixing ratios close to or in excess of the EU air quality standard for phytotoxicity. This underscores the sensitivity of the subtropical latitude belt to anthropogenic emissions.

The vicinity of these five locations to pollution sources is illustrated by the amplitude of the diel ozone cycle. In Los Angeles the local emissions are strongest, leading to a rapid photochemical ozone build-up during the day and nighttime titration by $\mathrm{NO}$ emissions. In Bahrain the diel amplitude is smaller because the ambient ozone levels are more strongly determined by long-distance transport. In Hunan and WAustralia the diel ozone amplitude is increasingly smaller at greater distance from strong $\mathrm{NO}_{\mathrm{x}}$ sources.

In marine environments such as Midway, with negligible local $\mathrm{NO}_{\mathrm{x}}$ sources, the diel ozone cycle is controlled by upwind photochemical destruction during daytime and the absence of photochemistry at night (de Laat and Lelieveld, 2000). The remoteness from $\mathrm{NO}_{\mathrm{x}}$ sources is also illustrated by the seasonal cycle of ozone. In polluted environments the season with the most intense sunlight is associated with the strongest ozone production, whereas in remote low- $\mathrm{NO}_{\mathrm{x}}$ locations photochemical ozone loss prevails. Usually in summer the influence of STE becomes negligible (Fig. 11). However, this is not the case in the Gulf region.

Surprisingly, during summer the daily mean ozone mixing ratios in Bahrain are similar to Los Angeles although daytime peak levels can be higher in the latter. In winter Los Angeles is subject to westerly winds that carry unpolluted Pacific air. Conversely, in Bahrain during winter ozone levels are substantially higher, i.e. permanently in excess of $40 \mathrm{ppbv}$, while the health hazardous level of 50-60 ppbv is exceeded between February and October, and the 80 ppbv level during most of the summer. As mentioned in the previous section, this is not only typical for Bahrain but rather for the entire region.

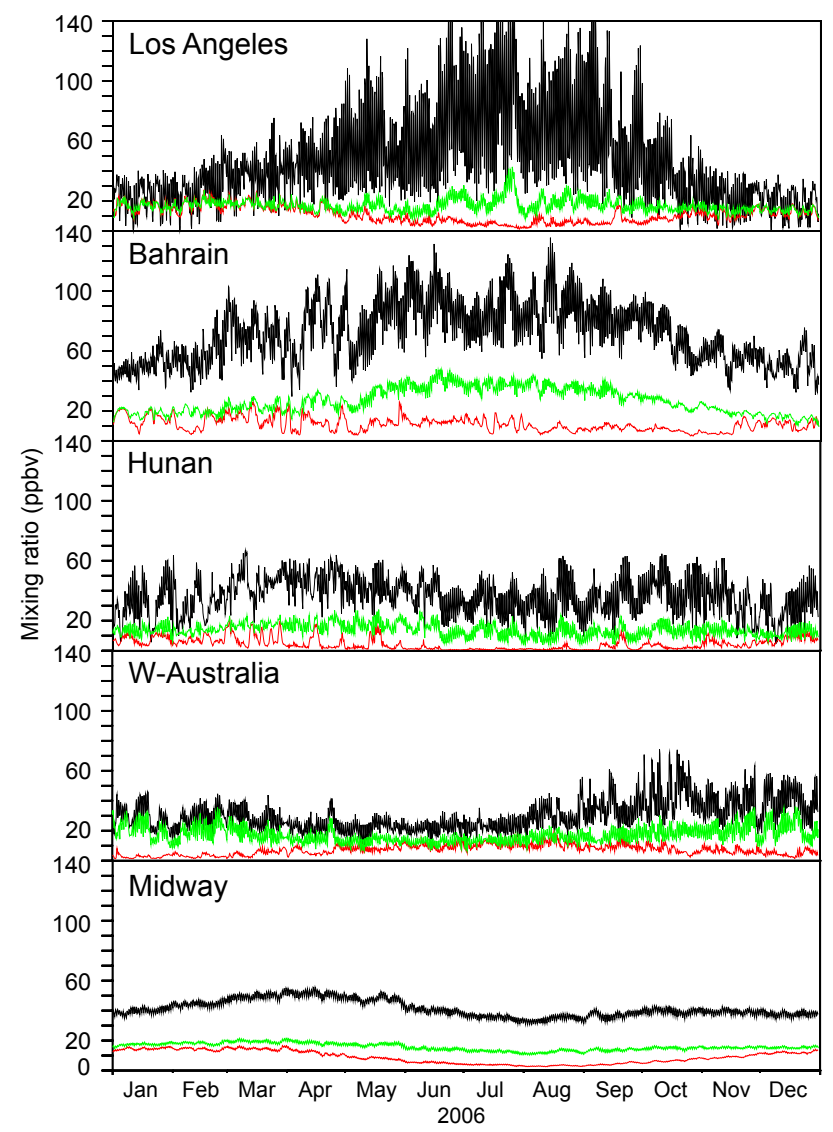

Fig. 11. Model calculated surface mixing ratios of $\mathrm{O}_{3}$ and $\mathrm{O}_{3} \mathrm{~s}$ (red) in the areas of Los Angeles $\left(117-119^{\circ} \mathrm{W}, 33-35^{\circ} \mathrm{N}\right)$, Bahrain (50$\left.52^{\circ} \mathrm{E}, 25-27^{\circ} \mathrm{N}\right)$, Hunan in China $\left(109-110^{\circ} \mathrm{E}, 26-28^{\circ} \mathrm{N}\right)$, West Australia $\left(118-120^{\circ} \mathrm{E}, 26-28^{\circ} \mathrm{S}\right)$ and the Pacific Midway Islands $\left(180^{\circ} \mathrm{E}-178^{\circ} \mathrm{W}, 26-28^{\circ} \mathrm{N}\right)$. The green lines show $\mathrm{O}_{3}$ with a model setup in which anthropogenic emissions were excluded.

\section{Regional ozone budget}

Figure 11 also shows model calculated ozone levels after excluding anthropogenic sources (in green). Generally, the diel and annual profiles much resemble clean maritime conditions and most locations have ozone mixing ratios of about 20 ppbv or less. Only in Bahrain during summer ozone levels approach $40 \mathrm{ppbv}$, indicating substantial influence from upwind natural $\mathrm{NO}_{\mathrm{x}}$ emissions, especially lightning ( $\mathrm{Li}$ et al., 2001). Clearly, in all locations, from urban to central Pacific, anthropogenic emissions have strongly influenced ozone mixing ratios as also indicated in previous work (Lelieveld and Dentener, 2000).

To compare the regional ozone budgets with and without anthropogenic influences, Tables 2 and 3 present the source and sink terms for the central Gulf region, the geographical area defined earlier for Fig. 6. We distinguish between the model diagnosed troposphere and boundary layer. The monthly mean tropospheric ozone columns are largest 
Table 2a. Boundary layer ozone budget in 2006 for the region $25^{\circ}-30^{\circ} \mathrm{N}$ and $45^{\circ}-55^{\circ} \mathrm{E}$ (units $\mathrm{Gg} / \mathrm{month}$ ).

\begin{tabular}{llllll}
\hline & $\begin{array}{l}\text { Burden } \mathrm{O}_{3} \\
\left(\Delta \mathrm{O}_{3}\right)^{\mathrm{a}}\end{array}$ & $\begin{array}{l}\text { Chemical } \\
\text { production }\end{array}$ & $\begin{array}{l}\text { Chemical } \\
\text { destruction }\end{array}$ & $\begin{array}{l}\text { Dry } \\
\text { deposition }\end{array}$ & $\begin{array}{l}\text { Net } \\
\text { transport }\end{array}$ \\
\hline January & $22(-1)$ & 276 & -43 & -128 & -106 \\
February & $17(-5)$ & 296 & -57 & -124 & -120 \\
March & $16(-1)$ & 435 & -103 & -161 & -172 \\
April & $17(1)$ & 533 & -152 & -164 & -216 \\
May & $21(4)$ & 679 & -219 & -172 & -284 \\
June & $42(21)$ & 716 & -247 & -186 & -262 \\
July & $39(-3)$ & 813 & -359 & -196 & -261 \\
August & $14(-25)$ & 702 & -280 & -167 & -280 \\
September & $22(8)$ & 535 & -166 & -143 & -218 \\
October & $18(-4)$ & 409 & -109 & -134 & -170 \\
November & $26(8)$ & 348 & -74 & -126 & -140 \\
December & $23(-3)$ & 246 & -38 & -109 & -102 \\
\hline
\end{tabular}

${ }^{\text {a }}$ The $\mathrm{O}_{3}$ burden change relative to the previous month in parentheses.

Table 2b. Tropospheric ozone budget in 2006 for the region $25^{\circ}-30^{\circ} \mathrm{N}$ and $45^{\circ}-55^{\circ} \mathrm{E}$ (units $\mathrm{Gg} / \mathrm{month}$ ).

\begin{tabular}{llllll}
\hline & $\begin{array}{l}\text { Burden } \mathrm{O}_{3} \\
\left(\Delta \mathrm{O}_{3}\right)^{\mathrm{a}}\end{array}$ & $\begin{array}{l}\text { Chemical } \\
\text { production }\end{array}$ & $\begin{array}{l}\text { Chemical } \\
\text { destruction }\end{array}$ & $\begin{array}{l}\text { Dry } \\
\text { deposition }\end{array}$ & $\begin{array}{l}\text { Net } \\
\text { transport }\end{array}$ \\
\hline January & $460(37)$ & 549 & -219 & -128 & -165 \\
February & $585(125)$ & 630 & -312 & -124 & -69 \\
March & $572(-13)$ & 997 & -475 & -161 & -374 \\
April & $446(-126)$ & 1240 & -672 & -164 & -530 \\
May & $663(217)$ & 1659 & -948 & -172 & -322 \\
June & $685(22)$ & 1789 & -1070 & -186 & -511 \\
July & $656(-29)$ & 1931 & -1384 & -196 & -380 \\
August & $632(-24)$ & 1839 & -1262 & -167 & -434 \\
September & $514(-118)$ & 1351 & -721 & -143 & -605 \\
October & $414(-100)$ & 955 & -512 & -134 & -409 \\
November & $490(76)$ & 698 & -334 & -126 & -162 \\
December & $567(77)$ & 490 & -179 & -109 & -125 \\
\hline
\end{tabular}

${ }^{\text {a }}$ The $\mathrm{O}_{3}$ burden change relative to the previous month in parentheses

from May to August ( $>600 \mathrm{Gg} \mathrm{O}_{3}$ ) and the boundary layer columns are maximum $(\sim 40 \mathrm{Gg})$ in June and July. During the latter two months the long-distance transport of polluted air from the Mediterranean is most efficient.

Both in the boundary layer and in the troposphere the photochemical ozone formation is strongest during the MayAugust period. By taking boundary layer chemical ozone production of $>500 \mathrm{Gg} / \mathrm{month}$ and tropospheric $\mathrm{O}_{3}$ production $>1000 \mathrm{Gg} / \mathrm{month}$ as criteria for strong ozone formation, it appears that the ozone buildup in the period AprilSeptember is generally very strong, coincident with the high surface ozone shown in Fig. 8. March and October are "transition" months during which air quality standards for human health are nevertheless exceeded. Table 2 furthermore shows that the troposphere over the Persian Gulf strongly contributes to net photochemical $\mathrm{O}_{3}$ formation and therefore exports substantial amounts of ozone (nearly $400 \mathrm{Gg} / \mathrm{month}$ ) to the surrounding regions.

Table 3 presents the regional tropospheric and boundary layer ozone budgets for the model simulations without anthropogenic emissions. Although chemical ozone production is still highest in the April-September period, it is more than a factor of three less in the boundary layer and a factor of 2.5 less in the troposphere compared to the recent conditions (Table 2). The relative ozone production enhancements are even stronger during winter, so that annually the chemical production is increased by more than a factor of four in the boundary layer and a factor of three in the troposphere.

The annual mean tropospheric ozone column over the Gulf in the simulation with only natural emissions is $311 \mathrm{Gg}$ whereas this is $557 \mathrm{Gg}$ in the simulation that also includes anthropogenic emissions. Even though the simulation without 
Table 3a. Boundary layer ozone budget for the region $25^{\circ}-30^{\circ} \mathrm{N}$ and $45^{\circ}-55^{\circ} \mathrm{E}$ for the simulation without anthropogenic emissions (units $\mathrm{Gg} / \mathrm{month})$.

\begin{tabular}{llllll}
\hline & $\begin{array}{l}\text { Burden } \mathrm{O}_{3} \\
\left(\Delta \mathrm{O}_{3}\right)^{\mathrm{a}}\end{array}$ & $\begin{array}{l}\text { Chemical } \\
\text { production }\end{array}$ & $\begin{array}{l}\text { Chemical } \\
\text { destruction }\end{array}$ & $\begin{array}{l}\text { Dry } \\
\text { deposition }\end{array}$ & $\begin{array}{l}\text { Net } \\
\text { transport }\end{array}$ \\
\hline January & $9(1)$ & 15 & -12 & -42 & 40 \\
February & $6(-3)$ & 24 & -18 & -45 & 36 \\
March & $6(0)$ & 47 & -28 & -56 & 37 \\
April & $6(0)$ & 94 & -50 & -59 & 15 \\
May & $10(4)$ & 195 & -89 & -74 & -28 \\
June & $21(11)$ & 249 & -114 & -88 & -36 \\
July & $19(-2)$ & 304 & -180 & -98 & -28 \\
August & $8(-11)$ & 230 & -137 & -83 & -21 \\
September & $8(0)$ & 149 & -70 & -62 & -17 \\
October & $8(0)$ & 75 & -41 & -51 & 17 \\
November & $8(0)$ & 43 & -25 & -43 & 25 \\
December & $8(0)$ & 17 & -10 & -34 & 27 \\
\hline
\end{tabular}

a The $\mathrm{O}_{3}$ burden change relative to the previous month in parentheses

Table 3b. Tropospheric ozone budget for the region $25^{\circ}-30^{\circ} \mathrm{N}$ and $45^{\circ}-55^{\circ} \mathrm{E}$ for the simulation without anthropogenic emissions (units $\mathrm{Gg} / \mathrm{month})$.

\begin{tabular}{llllll}
\hline & $\begin{array}{l}\text { Burden } \mathrm{O}_{3} \\
\left(\Delta \mathrm{O}_{3}\right)^{\mathrm{a}}\end{array}$ & $\begin{array}{l}\text { Chemical } \\
\text { production }\end{array}$ & $\begin{array}{l}\text { Chemical } \\
\text { destruction }\end{array}$ & $\begin{array}{l}\text { Dry } \\
\text { deposition }\end{array}$ & $\begin{array}{l}\text { Net } \\
\text { transport }\end{array}$ \\
\hline January & $263(29)$ & 88 & -91 & -42 & 74 \\
February & $373(110)$ & 104 & -131 & -45 & 182 \\
March & $324(-49)$ & 174 & -176 & -56 & 9 \\
April & $244(-80)$ & 313 & -274 & -59 & -60 \\
May & $369(125)$ & 616 & -442 & -74 & 25 \\
June & $371(2)$ & 778 & -534 & -88 & -154 \\
July & $365(-6)$ & 901 & -748 & -98 & -61 \\
August & $329(-36)$ & 811 & -677 & -83 & -87 \\
September & $264(-65)$ & 529 & -344 & -62 & -188 \\
October & $231(-33)$ & 289 & -234 & -51 & -37 \\
November & $241(10)$ & 179 & -146 & -43 & 20 \\
December & $355(114)$ & 88 & -69 & -34 & 129 \\
\hline
\end{tabular}

a The $\mathrm{O}_{3}$ burden change relative to the previous month in parentheses

anthropogenic influence indicates that the region exports ozone to its surroundings during summer, on an annual net basis the boundary layer imports ozone, whereas for the troposphere we compute a small net export $(148 \mathrm{Gg} / \mathrm{yr})$. This contrasts to a strong net export, several orders of magnitude higher $(4086 \mathrm{Gg})$ in the troposphere during the year 2006.

\section{Conclusions}

The ozone hot spot over the Persian Gulf predicted by our model is caused by a combination of factors that operate in the same direction. These include long-distance transport of air pollution, unusually strong STE, substantial upwind nat- ural $\mathrm{NO}_{\mathrm{x}}$ sources, a lack of deep convective mixing and precipitation, strong local anthropogenic emissions and highly favorable conditions for photochemistry. Together this leads to strongly enhanced ozone mixing ratios in the free troposphere, the boundary layer and at the Earth's surface.

Our model results, supported by satellite measurements, indicate that the Gulf region has changed from pre-industrial conditions with near-surface ozone mixing ratios below 40 ppbv, as derived from calculations without anthropogenic emissions, to present-day levels that strongly exceed air quality standards (as defined for the EU). Furthermore, the region has changed from near-neutral in terms of net ozone transport, into one that strongly contributes to net ozone transport. Considering a tropospheric ozone lifetime of several weeks, 
during which non-soluble gases can travel around the globe, this transport contributes to a hemispheric increase of ozone in the subtropics.

Although here we focus on 2006 it is important to emphasize that the ozone hot spot over the Persian Gulf is a recurrent feature in our model calculations for the period 19962006. Furthermore, a model simulation for the summer of 2006 at enhanced horizontal resolution $\left(\sim 1.1^{\circ}\right.$ lat/lon $)$ reproduces the ozone hot spot, indicating that the results presented here are not sensitive to the resolution of the model.

The high background ozone mixing ratios in the Gulf region, as determined by long-distance transport of air pollution, indicate that the local control options to substantially reduce surface ozone below health hazardous levels are limited, and that international efforts are called for. Nevertheless, satellite measurements indicate that tropospheric $\mathrm{NO}_{2}$ columns in the Gulf region and in general in urban and industrial regions in the Middle East are remarkably high. Reductions of air pollution emissions, which should be feasible e.g. in the transport and energy sectors, will help reduce ozone formation.

Our model has been extensively tested for many locations and we consider these results compelling. Further, data from satellites, aircraft measurements and in the upwind Mediterranean region indicate increasing trends of ozone and $\mathrm{NO}_{\mathrm{x}}$ emissions. Nevertheless, the lack of ground-based measurements in the Gulf region is unsatisfactory. We recommend that Global Atmospheric Watch stations in Saudi Arabia and Iran report the available data and that additional stations are set up to provide the information needed to effectively reduce air pollution. This will be particularly important as it may be expected that climate change will promote poor air quality conditions while ozone precursor emissions will likely continue to increase in the region.

Acknowledgements. We are grateful to V. Thouret, the MOZAIC (Measurements of Ozone and Water Vapor by In-service Airbus Aircraft) and TES (Tropospheric Emission Spectrometer on NASA's Aura satellite) teams for the use of data to test our model. We acknowledge the support of MOZAIC by the European Commission, Airbus and INSU-CNRS. Particular thanks to Lufthansa, Air France and Austrian Air for carrying the MOZAIC equipment free of charge since 1994. We also thank the European Commission for support of the EU project CIRCE (Climate Change and Impact Research: the Mediterranean Environment).

Edited by: R. Vautard

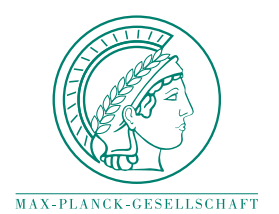

This Open Access Publication is financed by the Max Planck Society.

\section{References}

Ayres, J., Maynard, R., and Richards, R.: Air pollution and health, Imperial College Press, London, 2006.

Barret, B., Ricaud, P., Mari, C., Attié, J.-L., Bousserez, N., Josse, B., Le Flochmoën, E., Livesey, N.J., Massart, S., Peuch, V.H., Piacentini, A., Sauvage, B., Thouret, V., and Cammas, J.P.: Transport pathways of CO in the African upper troposphere during the monsoon season: a study based upon the assimilation of spaceborne observations, Atmos. Chem. Phys., 8, 3231-3246, 2008 , http://www.atmos-chem-phys.net/8/3231/2008/.

Bell, M. L., Peng, R. D., and Dominici, F.: The exposure-response curve for ozone and risk of mortality and the adequacy of current ozone regulations, Environ. Health Perspect., 114, 532-536, 2006.

Chen, D., Zhou, B., Beirle, S., Chen, L. M., and Wagner, T.: Tropospheric $\mathrm{NO}_{2}$ column densities deduced from zenith-sky DOAS measurements in Shanghai, China, and their application to satellite validation, Atmos. Chem. Phys. Discuss., 8, 16713-16762, 2008 , http://www.atmos-chem-phys-discuss.net/8/16713/2008/.

de Laat, A. T. J. and Lelieveld, J.: Diurnal ozone cycle in the marine boundary layer, J. Geophys. Res., 105, 11547-11559, 2000.

Diffenbaugh, N. S., Pal, J. S., Giorgi, F., and Gao, X.: Heat stress intensification in the Mediterranean climate change hotspot, Geophys. Res. Lett., 34, L11706, doi:10.1029/2007GL030000, 2007.

Duncan, B. N. and Bey, I: A modeling study of the export pathways of pollution from Europe: Seasonal and interannual variations (1987-1997), J. Geophys. Res., 109, D08301, doi:10.1029/2003JD004079, 2004.

Duncan, B. N., West, J. J., Fiore, A. M., and Ziemke, J. R.: The influence of European pollution on ozone in the Near East and northern Africa, Atmos. Chem. Phys., 8, 2267-2283, 2008, http://www.atmos-chem-phys.net/8/2267/2008/.

Emberson, L., Ashmore, M., and Murray, F.: Air pollution impacts on crops and forests. A global assessment, Imperial College Press, London, 2003.

Ganzeveld, L. N., van Aardenne, J., Butler, T., Lawrence, M. G., Metzger, S. M., Stier, P., Zimmerman, P., and Lelieveld, J.: Technical Note: Anthropogenic and natural offline emissions and the online EMissions and dry DEPosition (EMDEP) submodel of the Modular Earth Submodel System (MESSy), Atmos. Chem. Phys. Discuss., 6, 5457-5483, 2006, http://www.atmos-chem-phys-discuss.net/6/5457/2006/.

Giorgetta, M. A., Manzini, E., Roeckner, E., Esch, M., and Bengtsson, L.: Climatology and forcing of the quasi-biennial oscillation in the MAECHAM5 model, J. Climate, 19, 3882-3901, 2006.

Giorgi, F. and Bi, X.: Updated regional precipitation and temperature changes for the 21 st century from ensembles of recent AOGCM simulations, Geophys. Res. Lett., 32, L21715, doi:10.1029/2005GL024288, 2005.

Gryparis, A., Forsberg, B., Katsouyanni, K., et al.: Acute effects of ozone on mortality from the "Air pollution and health: A European approach" project, Am. J. Respir. Crit. Care Med., 170, 1080-1087, 2004.

Gurjar, B. R., Butler, T. M., Lawrence, M. G., and Lelieveld, J.: Evaluation of emissions and air quality in megacities, Atmos. Environ., 42, 1593-1606, 2008.

Held, I. M. and Soden, B. J.: Robust responses of the hydrological 
cycle to global warming, J. Climate, 19, 5686-5699, 2006.

Intergovernmental Panel on Climate Change (IPCC): Climate change 2007: The physical science basis; Contribution of working group I to the fourth assessment report of the IPCC, edited by: Solomon, S., Qin, D., Manning, M., et al., Cambridge University Press, Cambridge, UK, and New York, 2007.

Jöckel, P., Tost, H., Pozzer, A., Brühl, C., Buchholz, J., Ganzeveld, L., Hoor, P., Kerkweg, A., Lawrence, M. G., Sander, R., Steil, B., Stiller, G., Tanarhte, M., Taraborelli, D., van Aardenne, J., and Lelieveld, J.: The atmospheric chemistry general circulation model ECHAM5/MESSy: Consistent simulation of ozone from the surface to the mesosphere, Atmos. Chem. Phys., 6, 50675104, 2006,

http://www.atmos-chem-phys.net/6/5067/2006/.

Kerkweg, A., Sander, R., Tost, H., and Jöckel, P.: Technical note: Implementation of prescribed (OFFLEM), calculated (ONLEM), and pseudo-emissions (TNUDGE) of chemical species in the Modular Earth Submodel System (MESSy), Atmos. Chem. Phys., 6, 3603-3609, 2006,

http://www.atmos-chem-phys.net/6/3603/2006/.

Kallos, G., Kotroni, V., Lagouvardos, K., and Papadopoulos, A.: On the long-range transport of air pollutants from Europe to Africa, Geophys. Res. Lett., 25, 619-622, 1998.

Kentarchos, A. S., Roelofs, G.-J., and Lelieveld, J.: Simulation of extratropcal synoptic-scale stratosphere-troposphere exchange using a coupled chemistry GCM: Sensitivity to horizontal resolution, J. Atmos. Sci., 57, 2824-2838, 2000.

Kouvarakis, G., Vrekoussis, M., Mihalopoulos, N., Kourtidis, K., Rappenglueck, B., Gerasopoulos, E., and Zerefos, C.: Spatial and temporal variability of tropospheric ozone $\left(\mathrm{O}_{3}\right)$ in the boundary layer above the Aegean Sea (eastern Mediterranean), J. Geophys. Res., 107, 8137, doi:10.1029/2000JD000081, 2002.

Lelieveld J. and Dentener, F.: What controls tropospheric ozone? J. Geophys. Res., 105, 3531-3551, 2000.

Lelieveld, J., Berresheim, H., Borrmann, S., et al.: Global air pollution crossroads over the Mediterranean, Science, 298, 794-799, 2002

Lelieveld, J., van Aardenne, J., Fischer, H., de Reus, M., Williams, J., and Winkler, P.: Increasing ozone over the Atlantic Ocean, Science, 304, 1483-1487, 2004.

Lelieveld, J., Brühl, C., Jöckel, P., Steil, B., Crutzen, P.J., Fischer, H., Giorgetta, M. A., Hoor, P., Lawrence, M. G., Sausen, R., and Tost, H.: Stratospheric dryness: model simulations and satellite observations, Atmos. Chem. Phys., 7, 1313-1332, 2007, http://www.atmos-chem-phys.net/7/1313/2007/.

Leue, C., Wenig, M. Wagner, T., Klimm, O., Platt, U., and Jähne, B.: Quantitative analysis of $\mathrm{NO}_{2}$ emissions from GOME satellite image sequences, J. Geophys. Res., 106, 5493-5505, 2001.

Li., Q., Jacob, D. J., Logan, J. A., Bey, I., Yantosca, R. M., Liu, H., Martin, R. V., Fiore, A. M., Field, B. D., and Duncan, B. N.: A tropospheric ozone maximum over the Middle East, Geophys. Res. Lett., 28, 3235-3238, 2001.

Nassar R., Logan, J. A., Worden, H. M., et al.: Validation of Tropospheric Emission Spectrometer (TES) nadir ozone profiles using ozonesonde measurements, J. Geophys. Res., 113, D15S17, doi:10.1029/2007JD008819, 2008.

Neftel A., Spirig, C., Prévôt, A. S. H., Furger, M., Stutz, J., Vogel, B., and Hjorth, J.: Sensitivity of photooxidant production in the Milan Basin: An overview of results from a EUROTRAC-2 Lim- itation of Oxidant Production field experiment, J. Geophys. Res., 107, 8188, doi:10.1029/2001JD001263, 2002.

Osterman, G. B., Kulawik, S. S., Worden, H. ., Richards, N. A. D., Fisher, B. M., Eldering, A., Shephard, M. W., Froidevaux, L., Labow, G., Luo, M., Herman, R. L., Bowman, K. W., and Thompson, A. M.: Validation of Tropospheric Emission Spectrometer (TES) measurements of the total, stratospheric, and tropospheric column abundance of ozone, J. Geophys. Res., 113, D15S16, doi:10.1029/2007JD008801, 2008.

Pozzer, A., Jöckel, P., Tost, H., Sander, R., Ganzeveld, L., Kerkweg, A., and Lelieveld, J.: Simulating organic species with the global atmospheric chemistry general circulation model ECHAM5/MESSy1: a comparison of model results with observations, Atmos. Chem. Phys. 7, 2527-2550, 2007.

Ribas, A. and Peñuelas, J.: Temporal patterns of surface ozone levels in different habitats of the North Western Mediterranean basin, Atmos. Environ., 38, 985-992, 2004.

Roeckner, E., Brokopf, R., Esch, M., Giorgetta, M., Hagemann, S., Kornblüh, Manzini, L. E., Schlese, U., and Schulzweida, U.: Sensitivity of simulated climate to horizontal and vertical resolution in the ECHAM5 atmosphere model, J. Climate, 19, 37713791, 2006.

Rodwell, M. J. and Hoskins, B. J.: Monsoons and the dynamics of deserts, Q. J. R. Meteorol. Soc., 122, 1385-1404, 1996.

Rodwell, M. J. and Hoskins, B. J.: Subtropical anticyclones and the summer monsoon, J. Climate, 14, 3192-3211, 2001.

Roelofs, G. J. and Lelieveld, J.: Model study of the influence of cross-tropopause $\mathrm{O}_{3}$ transports on tropospheric $\mathrm{O}_{3}$ levels, Tellus, 49B, 38-55, 1997.

Sander, R., Kerkweg, A., Jöckel, P., and Lelieveld, J.: Technical Note: The new comprehensive atmospheric chemistry module MECCA, Atmos. Chem. Phys., 5, 445-450, 2005, http://www.atmos-chem-phys.net/5/445/2005/.

Seidel, D. J., Fu, Q., Randel, W. J., and Reichler, T. J.: Widening of the tropical belt in a changing climate, Nature Geosc. 1, 21-24, 2008.

Singh, H. B., Chen, Y., Thakur, A. N., Kondo, Y., Talbot, R. W., Gregory, G. L., Sachse, G. W., Blake, D. R., Bradshaw, J. D., Wang, Y., and Jacob, D. J.: Latitudinal distribution of reactive nitrogen in the free troposphere over the Pacific Ocean in late winter/early spring, J. Geophys. Res., 103, 28237-28246, 1998.

Sprenger, M., Maspoli, M. C., and Wernli, H.: Tropopause folds and cross-tropopause exchange: A global investigation based upon ECMWF analyses for the time period March 2000 to February 2001, J. Geophys. Res., 108, 8518, doi:10.1029/2002JD002587, 2003.

Stohl, A., Eckhardt, S., Forster, C., James, P., and Spichtinger, N.: On the pathways and timescales of intercontinental air pollution transport, J. Geophys. Res., 107, 4684, doi:10.1029/2001JD001396, 2002.

Stavrakou, T., Müller, J.-F., Boersma, K. F., De Smedt, I., and van der A., R. J.: Assessing the distribution and growth rates of $\mathrm{NO}_{\mathrm{x}}$ emission sources by inverting a 10-year recors of $\mathrm{NO}_{2}$ columns, Geophys. Res. Lett., 35, L10801, doi:10.1029/2008GL033521, 2008.

Sun, Y., Solomon, S., Dai, A., and Portmann, R. W.: How often will it rain? J. Climate, 20, 4801-4818, 2007.

Thouret, V., Marenco, A., Logan, J. A., Nédélec, P., and Grouhel, C.: Comparisons of ozone measurements from the MOZAIC air- 
borne program and the ozone sounding network at eight locations, J. Geophys. Res., 103, 695-720, 1998.

Tost, H., Jöckel, P., Kerkweg, A., Sander, R., and Lelieveld, J.: Technical Note: A new comprehensive SCAVenging submodel for global atmospheric chemistry modelling, Atmos. Chem. Phys., 6, 565-574, 2006,

http://www.atmos-chem-phys.net/6/565/2006/.

Traub., M. and Lelieveld, J.: Cross-tropopause transport over the eastern Mediterranean, J. Geophs. Res. 108, 4712, doi:10.1029/2003JD003745, 2003.

van der A., R. J., Eskes, H. J., Boersma, K. F., van Noije, T. P. C., van Roozendaal, M., de Smedt, I., Peters, D. H. M. U, and Meijer, E. W.: Trends, seasonal variability and dominant $\mathrm{NO}_{\mathrm{x}}$ sources derived from a ten year record of $\mathrm{NO}_{2}$ measured from space, J. Geophys. Res., 113, D04302, doi:10.1029/2007JD009021, 2008.

van Aardenne, J. A., Dentener, F., Olivier, J. G. G., Peters, J. A. H. W., and Ganzeveld, L. N.: The EDGAR3.2 Fast Track 2000 dataset (32FT2000), Tech. rep., Joint Research Centre, Institute for Environment and Sustainability (JRC-IES), Climate Change Unit, TP280, 21020, Ispra (Va), Italy, http://www.mnp.nl/edgar/ model/v32ft2000edgar/docv32ft2000/, 2005.
Vardavas, I. M. and Taylor, F. W.: Radiation and climate, Oxford University Press, Oxford, UK, 2007.

Worden, H. M., Logan, J. A., Worden, J. R., Beer, R., Bowman, K., Clough, S. A., Eldering A., Fischer, B. M., Gunson, M. R., Herman, R. L., Kulawik, S. S., Lampel., M. C., Luo, M., Megretskaia, I. A., Osterman, G. B., and Shephard, M. W.: Comparisons of Tropospheric Emission Spectrometer (TES) ozone profiles to ozonesondes: Methods and initial results, J. Geophys. Res., 112, D03309, doi:10.1029/2006JD007258, 2007.

Zbinden, R. M., Cammas, J.-P., Thouret, V., Nédélec, P., Karcher, F., and Simon, P.: Mid-latitude tropospheric ozone columns from the MOZAIC program: climatology and interannual variability, Atmos. Chem. Phys., 6, 1053-1073, 2006, http://www.atmos-chem-phys.net/6/1053/2006/. 